\title{
Recombinant bovine interferon-t enhances in vitro development of bovine embryos by upregulating expression of connexin 43 and E-cadherin
}

\author{
Zhong-Jian Bao, ${ }^{*} \dagger^{1}$ Shuan Zhao, ${ }^{* 1}$ Ihtesham UI Haq, ${ }^{*}$ and Shen-Ming Zeng ${ }^{* 2}$ \\ *National Key Laboratory of Animal Nutrition, Laboratory of Animal Embryonic Biotechnology; National Engineering Laboratory \\ for Animal Breeding; Key Laboratory of Animal Genetics, Breeding, and Reproduction of the Ministry of Agriculture, \\ College of Animal Science and Technology, China Agricultural University, Beijing, 100193, China \\ †Shenzhen Zhongshan Urology Hospital, Assisted Reproductive Technology Center, Shenzhen, 518045, China
}

\section{ABSTRACT}

Interferon- $\tau$ (IFNT), produced in ruminants by embryonic trophoblastic cells before implantation, is involved in the maternal recognition of pregnancy. It is a pleiotropic molecule that alters the synthesis of endometrial proteins and inhibits the proliferation of some cells. The present study investigated the effects of recombinant bovine IFNT on the development of earlystage bovine embryos and the molecular mechanism underlying this effect. This study demonstrated that expression of mRNA encoding type I IFN receptor subunits was detectable from d 4 to 8 in in vitro fertilized (IVF) bovine embryos. A considerable number of IVF $(\mathrm{n}=1,941)$ and parthenogenetic activated $(\mathrm{n}=1,552)$ bovine embryos demonstrated that supplementing the culture medium with IFNT $(100 \mathrm{ng} / \mathrm{mL})$ produced a greater percentage of blastocysts, and the total cell number within the resulting blastocysts was higher. In addition, IFNT upregulated the expression levels of both mRNA and protein for connexin 43 (GJA1) and Ecadherin (CDH1) and expression levels for granulocytemacrophage colony-stimulating factor and insulin-like growth factor 2 mRNA but not for their proteins in $\mathrm{d}$ 8 embryos. However, IFNT inhibited mRNA expression for leukemia inhibitory factor (LIF), LIF receptor $\alpha$, and the sodium/potassium-transporting ATPase subunit $\beta-1$. We concluded that IFNT promoted the development of bovine embryos by upregulating the expression of GJA1 and CDH1. Thus, supplementing embryo cultures or transfer medium with IFNT may stimulate embryo development and improve embryo transfer efficiency.

Key words: interferon- $\tau$, embryo development, bovine

Received March 4, 2014.

Accepted August 10, 2014.

${ }^{1}$ Zhong-Jian Bao and Shuan Zhao contributed equally to this work.

${ }^{2}$ Corresponding author: zengsm@cau.edu.cn or zengshenming@ gmail.com

\section{INTRODUCTION}

Interferon- $\boldsymbol{\tau}$ (IFNT), an important pregnancy factor, is secreted in bovines by mononuclear trophectoderm cells of elongating ruminant conceptuses from d 16 to d 26 (Bartol et al., 1985; Geisert et al., 1988). Interferon- $\tau$ exerts its biological activities by binding to the type I interferon receptor (IFNAR), which consists of 2 transmembrane chains, IFNAR1 and IFNAR2, associated with protein-tyrosine kinase 2 (Tyk2) and Janus kinase 1 (Jak1), respectively. The binding of IFN to the receptor complex induces activation of Jak-signal transducer and activator of transcription (STAT) or non-STAT signaling pathways (Payelle-Brogard and Pellegrini, 2010). Previously, IFNAR was thought to be expressed only in the endometrium (Han et al., 1997) and not in conceptuses until at least $15 \mathrm{~d}$ of pregnancy. However, a recent report demonstrated the expression of IFNAR1 at earlier stages in ovine conceptuses (Imakawa et al., 2002) and in bovine embryos from the morula to blastocyst stage (Takahashi et al., 2003). Our recent research revealed that IFNT acts as an autocrine factor to regulate ovine trophectoderm cell proliferation (Wang et al., 2013). However, the role and underlying mechanisms of IFNT effects in early bovine embryo development remain unclear.

Many genes are involved in regulating the early stages of bovine embryo development. Connexin 43 (GJA1; gap junction protein alpha-1, $43 \mathrm{kDa}$ ) is 1 of 4 connexins that contribute to the development of gap junctions in the preimplantation embryo (De Sousa et al., 1997). The increase in GJA1 was found to be dependent on the Jak-STAT signal transduction pathway in murine cortical astrocytes (Ozog et al., 2004). Bovine embryos cultured in vitro exhibited a lower expression of GJA1 and were associated with changes in embryo quality (Rizos et al., 2002). Similarly, E-cadherin (CDH1), a catenin-associated cell surface adhesion molecule, displayed a significantly lower level in bovine blastocysts cultured in vitro compared with those derived in vivo (Wrenzycki et al., 2001). Granulocyte-macrophage colony-stimulating factor (GM-CSF) is a pleiotropic 
regulatory molecule originally identified as a product of activated $\mathrm{T}$ lymphocytes involved in proliferation and differentiation of hematopoietic cells (Ruef and Coleman, 1990). The addition of recombinant bovine GMCSF to serum-free medium 8 to $10 \mathrm{~h}$ after insemination increased the percentage of bovine oocytes that formed blastocysts (de Moraes and Hansen, 1997).

Insulin-like growth factor 2 (IGF2) is known as a mitogenic and differentiation-promoting growth factor (Harvey and Kaye, 1992), and its mRNA and protein are expressed in the preimplantation mouse embryo (Rappolee et al., 1992). Leukemia inhibitory factor (LIF) and the LIF receptor $\alpha$ (LIFR) play essential roles in early differentiation and implantation of embryos, and abundant levels of mRNA have been detected in bovine blastocysts produced in vitro (Niemann and Wrenzycki, 2000; Rizos et al., 2003). Both the $\alpha$ and $\beta$ subunits in the sodium/potassiumtransporting ATPase are expressed throughout early bovine development (Betts et al., 1997). Expression of the sodium/potassium-transporting ATPase subunit $\beta-1$ (ATP1B1) is required for blastocyst formation and normal assembly of trophectoderm tight junctionassociated proteins (Madan et al., 2007).

Although culture medium supplemented with IFNT reportedly promotes the proliferation of ovine trophectoderm and in vitro development of bovine embryos (Takahashi et al., 2003; Wang et al., 2013), large quantities of embryos are required to confirm this hypothesis before applying this strategy to in vivo transfer. Therefore, our objectives were to investigate the effects of IFNT on the early development of and relative gene expression in bovine embryos.

\section{MATERIALS AND METHODS}

All chemicals and media were tested using cell culture by the suppliers and purchased from Sigma Chemical Co. (St. Louis, MO) unless otherwise stated. All plasticware was from Nunc (Nalge Nunc International, Roskilde, Denmark). Recombinant bovine IFNT (1.13 $\times 10^{8}$ IU of antiviral activity $/ \mathrm{mg}$ ) was generously provided by R. Michael Roberts (University of Missouri, Columbia).

\section{Collection and In Vitro Maturation of Bovine Oocytes}

Bovine ovaries were obtained from a local abattoir and shipped to the laboratory within 3 to $4 \mathrm{~h}$ after collection in a temperature-controlled flask $\left(28-32^{\circ} \mathrm{C}\right)$ containing physiological saline solution $(0.9 \% \mathrm{NaCl})$ with $75 \mu \mathrm{g} / \mathrm{mL}$ penicillin and $50 \mu \mathrm{g} / \mathrm{mL}$ streptomycin. The cumulus-oocyte complexes (COC) were aspirated from antral follicles $(2-8 \mathrm{~mm}$ in diameter) with a sterile 18-gauge needle attached to a disposable syringe. All oocytes with a homogeneous cytoplasm and at least 3 intact layers of surrounding cumulus cells were selected for in vitro maturation. After rinsing the COC 3 times in prewarmed maturation medium consisting of TCM 199 with Earle's salts (Gibco/BRL, Grand Island, NY), $10 \%$ (vol/vol) fetal bovine serum (FBS, HyClonePierce, Shanghai, China), $10 \mu \mathrm{g} / \mathrm{mL}$ FSH (Bioniche, Belleville, ON, Canada), $10 \mu \mathrm{g} / \mathrm{mL}$ LH (Bioniche), 1 $\mathrm{ng} / \mathrm{mL}$ epidermal growth factor, and $0.1 \mathrm{mg} / \mathrm{mL}$ cysteine, groups of 20 to $25 \mathrm{COC}$ were cultured in $50-\mu \mathrm{L}$ medium droplets under mineral oil at $38.5^{\circ} \mathrm{C}$ and $5 \%$ $\mathrm{CO}_{2}$ in air with maximum humidity for 22 to $24 \mathrm{~h}$.

\section{Effect of IFNT on Development of Bovine Embryos}

After maturation, bovine COC were washed 3 times and then placed in a $50-\mu \mathrm{L}$ droplet of Brackett-Oliphant (BO) medium (Brackett and Oliphant, 1975) containing $10 \mathrm{mg} / \mathrm{mL}$ BSA under mineral oil for in vitro fertilization (IVF) as follows. Frozen semen (Beijing Dairy Cow Center, Beijing, China) were thawed in a water bath at $37^{\circ} \mathrm{C}$ for $30 \mathrm{~s}$. The sperm cells were washed twice in $\mathrm{BO}$ medium with $2.5 \mathrm{~m} M$ caffeine, and the sperm pellet was resuspended in $\mathrm{BO}$ medium supplemented with $10 \mathrm{mg} / \mathrm{mL}$ BSA and $5 \mathrm{IU} / \mathrm{mL}$ heparin. The number of spermatozoa was counted using a hemocytometer and then diluted in $\mathrm{BO}$ medium to a concentration of $2 \times 10^{6} / \mathrm{mL}$. An aliquot $(50 \mu \mathrm{L})$ of this suspension was added into each $50-\mu \mathrm{L}$ droplet of BO medium containing 20 oocytes under mineral oil for insemination. The IVF was carried out in humidified air with $5 \% \mathrm{CO}_{2}$ at $38.5^{\circ} \mathrm{C}$. After incubation for 6 to $8 \mathrm{~h}$, loosely associated cumulus cells and spermatozoa were removed from the COC using gentle vortexing. The presumptive zygotes were first cultured in CR1aa medium supplemented with $1 \%$ EAA and $1 \%$ NEAA and $3 \mathrm{mg} / \mathrm{mL}$ BSA for $2 \mathrm{~d}$ and then continuously cultured in CR1aa medium containing $10 \% \mathrm{FBS}$ at $38.5^{\circ} \mathrm{C}$ in a humidified atmosphere of $5 \% \mathrm{CO}_{2}$. The concentration of IFNT $(100 \mathrm{ng} / \mathrm{mL})$ was selected based on our previous study (Wang et al., 2013) and another article (Takahashi et al., 2003). The IFNT was added to the culture medium from d 4 to 8 . Half of the culture medium per microdrop was refreshed every 2 d. On d 4, 6 , and 8 after fertilization, embryos from each microdrop were harvested and used for gene expression and protein analyses.

\section{Effect of IFNT on the Development of Bovine Parthenogenetic Embryos}

The activation of matured oocytes was conducted according to the following protocol. Cumulus cells 
were removed from oocytes using $0.1 \%$ hyaluronidase after in vitro maturation. Oocytes were rinsed 3 times in $\mathrm{H} 199$ containing $10 \% \mathrm{FBS}$ and pretreated in $5 \mu \mathrm{M}$ ionomycin at $38.5^{\circ} \mathrm{C}$ for $5 \mathrm{~min}$. They were cultured in CR1aa supplemented with $2 \mathrm{mM}$ 6-DMAP (6-dimethylaminopurine) for $4 \mathrm{~h}$. The oocytes were first cultured in CR1aa medium with $3 \mathrm{mg} / \mathrm{mL}$ BSA for $2 \mathrm{~d}$ and then continuously cultured in CR1aa medium with $10 \%$ FBS for $4 \mathrm{~d}$ at $38.5^{\circ} \mathrm{C}$ in a humidified atmosphere of $5 \%$ $\mathrm{CO}_{2}$. A total of $100 \mathrm{ng} / \mathrm{mL}$ of IFNT was added to the culture medium from d 4 to 8 , and the culture medium was changed every $2 \mathrm{~d}$. The embryos in each medium were recovered for experimentation on d 4,6, or 8 after parthenogenesis activation.

\section{Blastocyst Cell Count}

The nuclei of 30 to 45 ( $\mathrm{n}=3$ to 5 per experimental group) IVF blastocysts were stained with Hoechst $33342(10 \mathrm{ng} / \mathrm{mL})$ for $10 \mathrm{~min}$ and then washed 3 times in Dulbecco's PBS. Embryos with nuclei labeled under UV excitation were individually mounted on microscope slides in glycerol beneath a coverslip and examined as a whole-mount preparation.

\section{Quantitative PCR}

Total cellular RNA from d 4 embryos, d 6 early blastocysts, and d 8 blastocysts was extracted using an RNAprep Pure tissue kit (Tiangen Biotech, Beijing, China). The RNA content was quantified and purity was determined using a NanoDrop ND 1000 spectrophotometer (Wilmington, DE). For RNA extraction, 100 embryos (4-5 microdrops, 20-25 embryos per microdrop) from each treatment group were used. From each sample, total cellular RNA (500 ng) was used for cDNA synthesis. In the first step, secondary structures were removed and an oligo (dT)-18 primer was annealed to the mRNA by heating the sample at $70^{\circ} \mathrm{C}$ for $5 \mathrm{~min}$. The reaction was quenched rapidly on ice and $5 \times$ reverse transcriptase $(\mathbf{R T})$ buffer, 10 $\mathrm{m} M$ deoxyribonucleotide triphosphates, $2 \mathrm{~m} M$ dithiothreitol, $20 \mathrm{U}$ of RNase inhibitor (TaKaRa Biotech, Dalian, China), and 200 U of Moloney murine leukemia virus (M-MLV) RT (Tiangen Biotech) were added (total reaction mixture volume of $25 \mu \mathrm{L}$ ). This mixture was heated at $42^{\circ} \mathrm{C}$ for $60 \mathrm{~min}$ and then at $70^{\circ} \mathrm{C}$ for $15 \mathrm{~min}$ to terminate the reaction. For each sample, a complete reaction without RT was also performed. Amplification reactions were conducted on a 96-well thermal cycler (Applied Biosystems, Foster City, CA) in a $20-\mu \mathrm{L}$ reaction volume containing $1 \mu \mathrm{L}$ of cDNA, 9 $\mu \mathrm{L}$ of $2 \times$ Master SYBR Green mix (Tiangen Biotech), $9 \mu \mathrm{L}$ of sterile water, and $0.5 \mu \mathrm{L}$ each of forward and reverse gene-specific primers $(10 \mu M)$. The primers and GenBank accession numbers for each gene are shown in (Table 1). The relative expression of each gene was calculated using the $2^{-\Delta \Delta \mathrm{Ct}}$ method (Livak and Schmittgen, 2001).

\section{Western Blot}

In total, 100 embryos (4-5 microdrops, 20-25 embryos per microdrop) from each treatment group were lysed in Laemmle sample buffer (Bio-Rad Laboratories, Hercules, CA). Equal amounts of proteins were separated using SDS-PAGE (7.5\% acrylamide running gel) and transferred to a nitrocellulose membrane (BioTrace NT, Pall Corp., Port Washington, NY). Nonspecific binding to the membrane was blocked with $5 \%$ nonfat milk in Tris-buffered saline-Tween (10 $\mathrm{m} M$ Tris, $\mathrm{pH}$ 7.5, $150 \mathrm{mM} \mathrm{NaCl}$, and $0.1 \%$ Tween 20 ) at room temperature for $1 \mathrm{~h}$. The membranes were then incubated with primary antibodies $\left(4^{\circ} \mathrm{C}\right.$, overnight), washed in Tris-buffered saline containing $0.1 \%$ Tween, and incubated with horseradish peroxidase-conjugated secondary antibodies at room temperature for $1 \mathrm{~h}$. The antibodies against GJA1 (H-150, sc-9059) and anti- $\beta$-actin (sc-47778) were purchased from Santa Cruz Biotech (Dallas, TX), anti-CDH1 (07-697) was purchased from Millipore (Billerica, MA), and mouse anti-bovine-GMCSF (MCA1828) was purchased from Serotec (AbDSerotec, Bio-Rad Laboratories). The protein bands were visualized using enhanced chemiluminescence detection reagents (Applygen Technologies Inc., Beijing, China) and X-Omat BT film (Kodak, Rochester, NY) according to the manufacturer's instructions. The films were digitized and densitometry analysis was performed with ImageJ 1.45s software (National Institutes for Health, Bethesda, MD; http://imagej.nih.gov/ij/). The relative intensity of the bands was quantified and normalized to the respective loading control.

\section{ELISA}

Bovine IGF2 content from 60 to 75 IVF blastocysts at d 6 or 8 (3 microdrops, 20-25 embryos per microdrop) was determined ( $\mathrm{n}=3-5$ per experimental group) using commercially available ELISA kits (Shanghai Yifeng Biochem Tech Co. Ltd., Shanghai, China). The ELISA was performed according to the manufacturer's instructions.

\section{Statistical Analysis}

Experiments were replicated on different days, using one or more microdrops of embryos per treatment on each day. Data were analyzed by least-squares ANOVA 
Table 1. Primer pairs $(\mathrm{F}=$ forward; $\mathrm{R}=$ reverse $)$ used for detection of $\mathrm{mRNA}$

\begin{tabular}{|c|c|c|c|}
\hline Gene $^{1}$ & PCR primer $\left(5^{\prime}\right.$ to $\left.3^{\prime}\right)$ & $\begin{array}{l}\text { Fragment } \\
\text { size (bp) }\end{array}$ & $\begin{array}{l}\text { GenBank } \\
\text { accession number }\end{array}$ \\
\hline IFNAR 1 & $\begin{array}{l}\text { F: CGACCCTGATGCTGGTCGCT } \\
\text { R: TGCACATCTGGGGGACCAATCTG }\end{array}$ & 376 & NM174552.2 \\
\hline IFNAR2 & $\begin{array}{l}\text { F: TCCACGGAGGGGTCTGAGGG } \\
\text { R: GGGGTTGGTGAAGGGCAGCT }\end{array}$ & 210 & NM174553.2 \\
\hline$C D H 1$ & $\begin{array}{l}\text { F: TTCCCGCCATCCTGGGGATCC } \\
\text { R: GGGTGTCATCTTCTGGGGGCAGT }\end{array}$ & 126 & AB037667.1 \\
\hline GJA1 & $\begin{array}{l}\text { F: GCCCATGTCTCCTCCCGGGT } \\
\text { R: GCTGGCTCTGCTGGAAGGCC }\end{array}$ & 268 & J05535.1 \\
\hline$G M-C S F$ & $\begin{array}{l}\text { F: GGGCACTGTGGTCTGCAGCT } \\
\text { R: ATCCACATGCTGCCAGGGCC }\end{array}$ & 76 & $\mathrm{U} 22385.1$ \\
\hline IGF2 & $\begin{array}{l}\text { F: TGTGGGGACCGCGGCTTCTA } \\
\text { R: CAGGGCCAGGTCGCAGCTTC }\end{array}$ & 105 & NM_174087.3 \\
\hline$L I F$ & $\begin{array}{l}\text { F: AGCAACGTGCTCTGCCGCTT } \\
\text { R: AGGTGTCGGGGCCGTAGGTC }\end{array}$ & 73 & NM_173931.1 \\
\hline LIFR & $\begin{array}{l}\text { F: TCTCCGGTGGCTGAGCGTCC } \\
\text { R: TGCTCCCGGGTTCGCTAGCT }\end{array}$ & 111 & XM_005221613.1 \\
\hline$A T P 1 B 1$ & $\begin{array}{l}\text { F: ATGGCCCGCGGAAAAGCCAA } \\
\text { R: GCCCGCCAGGCAGCCATAAA }\end{array}$ & 114 & NM_001035334.1 \\
\hline$G A P D H$ & $\begin{array}{l}\text { F: CGCCTGGAGAAACCTGCCAAGT } \\
\text { R: CACCACCCTGTTGCTGTAGCCA }\end{array}$ & 234 & NM001190390 \\
\hline
\end{tabular}

using the general linear model procedure of SAS software (version 9.1, SAS Institute Inc., Cary, NC). For the analysis of embryo development, each microdrop was considered to be an experimental unit, and cleavage and blastocyst development rates were calculated within each microdrop. The data for relative expression of connexin 43, E-cadherin, GM-CSF, IGF2, LIF, LIFR, and ATP1B1 were analyzed using a general linear model and one-way ANOVA followed by post hoc tests using the MIXED procedure models of SAS. All data are expressed as means \pm standard errors of the mean. The percentages were subjected to arcsine transformation before analysis. Differences were considered significant when the $P$-value was $<0.05$.

\section{RESULTS}

\section{Bovine Embryos Express IFNAR1 and IFNAR2 from $d 4$ to 8 after IVF}

To investigate the autocrine role for IFNT in the development of bovine embryos, we examined the mRNA expression of IFNAR1 and IFNAR2 using RT-PCR on extracts from d 4, 6, and 8 IVF embryos. Expression of IFNAR $1 \mathrm{mRNA}$ was detectable on $\mathrm{d} 4$ and 6 and was sharply increased at $\mathrm{d} 8$. However, expression of IFNAR2 mRNA was detectable and stable from d 4 to 8 (Figure 1).

\section{IFNT Promotes In Vitro Development of Bovine Embryos}

The presumptive bovine zygotes from IVF or PA were randomly assigned to the control or IFNT treatment groups. When IFNT $(100 \mathrm{ng} / \mathrm{mL})$ was added to the culture medium from $\mathrm{d} 4$, the embryos developed to the blastocyst stage at a significantly greater rate, and the number of cells within the resulting blastocysts was greater than that in controls after IVF (Table 2, Figure 2; $P<0.05$ ) and PA (Table $3 ; P<0.05$ ) in d 8 embryos. However, the rate at which blastocysts hatched was unaffected $(P>0.05)$ by treatment. We concluded that IFNT promoted the early stages of embryo development in bovines.

Table 2. Effects of IFN- $\tau$ (IFNT) on the development (mean \pm SEM) of bovine in vitro fertilized embryos

\begin{tabular}{lccccc}
\hline $\begin{array}{l}\text { IFNT } \\
(\mathrm{ng} / \mathrm{mL})\end{array}$ & $\begin{array}{c}\text { No. of } \\
\text { microdrops }\end{array}$ & $\begin{array}{c}\text { Cleavage } \\
\text { rate (\%) }\end{array}$ & $\begin{array}{c}\text { Blastocyst } \\
\text { rate (\%) }\end{array}$ & $\begin{array}{c}\text { Hatched blastocyst } \\
\text { rate (\%) }\end{array}$ & $\begin{array}{c}\text { Blastocyst } \\
\text { cell number }\end{array}$ \\
\hline 0 & 40 & $73.5 \pm 5.3$ & $50.2 \pm 2.2$ & $44.0 \pm 2.0$ & $116.0 \pm 3.0$ \\
100 & 40 & $75.8 \pm 3.9$ & $57.2 \pm 6.1^{*}$ & $44.7 \pm 1.9$ & $130.4 \pm 4.1^{*}$ \\
\hline
\end{tabular}

${ }^{1}$ Total oocyte number was 979 and 962 for 0 and $100 \mathrm{ng} / \mathrm{mL}$ treatments, respectively.

$* P<0.05$. 
Table 3. Effects of IFN- $\tau$ (IFNT) on the development (mean \pm SEM) of bovine parthenogenetic embryos

\begin{tabular}{lccccc}
\hline $\begin{array}{l}\text { IFNT } \\
(\mathrm{ng} / \mathrm{mL})\end{array}$ & $\begin{array}{c}\text { No. of } \\
\text { microdrops }\end{array}$ & $\begin{array}{c}\text { Cleavage } \\
\text { rate (\%) }\end{array}$ & $\begin{array}{c}\text { Blastocyst } \\
\text { rate (\%) }\end{array}$ & $\begin{array}{c}\text { Hatched blastocyst } \\
\text { rate (\%) }\end{array}$ & $\begin{array}{c}\text { Blastocyst } \\
\text { cell number }\end{array}$ \\
\hline 0 & 32 & $91.5 \pm 4.3$ & $53.5 \pm 5.7$ & $39.0 \pm 3.9$ & $58.4 \pm 1.5$ \\
100 & 32 & $88.4 \pm 5.1$ & $66.9 \pm 7.6^{*}$ & $40.2 \pm 3.4$ & $66.5 \pm 2.4^{*}$ \\
\hline
\end{tabular}

${ }^{1}$ Total oocyte number was 772 and 780 for 0 and $100 \mathrm{ng} / \mathrm{mL}$ treatments, respectively.

$* P<0.05$.

\section{Effect of IFNT on Gene and Protein Expression in Bovine IVF Embryos}

We explored the mechanism underpinning the promoting effect of IFNT on embryonic development using quantitative RT-PCR to detect the mRNA expression of connexin 43, E-cadherin, GM-CSF, IGF2, LIF, LIFR, and ATP1B1 in d 6 and 8 embryos. As shown in Figure 3, supplemental IFNT treatment increased the mRNA expression of GJA1 and GM-CSF in d 8 embryos (Figure 3A and $\mathrm{C} ; P<0.05$ ), and $C D H 1$ and $I G F 2$ in both $\mathrm{d} 6$ and 8 embryos (Figure 3B and $\mathrm{D} ; P<$ $0.05)$. However, IFNT treatment inhibited the expression of LIF, LIFR, and ATP1B1 mRNA in d 8 embryos (Figure 3E, F, and G; $P<0.05$ ).

The protein expression levels for these genes were also examined. As shown in Figure 4, IFNT treatment (100 $\mathrm{ng} / \mathrm{mL}$ ) significantly upregulated the levels of GJA1 and CDH1 (Figure 4A, B, and C; $P<0.05$ ), whereas IFNT did not affect the protein level of GM-CSF (Figure 4A and D; $P>0.05$ ) in d 8 bovine embryos. Moreover, the secretion of IGF2 was not significantly different in the control and IFNT-treated groups (Figure $4 \mathrm{E} ; P>0.05)$.
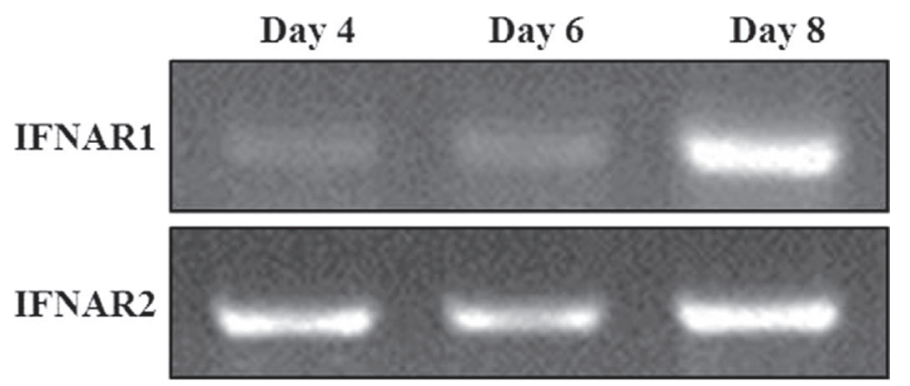

GAPDH

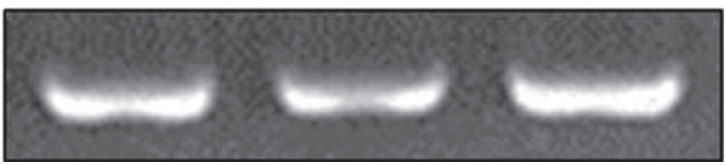

Figure 1. Bovine in vitro fertilized embryos express type I IFN receptor 1 and 2 (IFNAR1 and IFNAR2) from d 4 to 8. Bovine embryos were collected at d 4,6, and 8 after in vitro fertilization, and mRNA expression levels of IFNAR1 and IFNAR2 were detected using reverse transcription-PCR followed by agarose gel electrophoresis; $G A P D H$ served as an internal control.

\section{DISCUSSION}

An early study reported that IFN had no negative effects on the development of mice embryos in vitro (Carthew et al., 1986). Survival and implantation rates of the mouse embryo are promoted by perfusion of IFNT into the abdominal cavity (Assal-Meliani et al., 1995). The rate of blastocyst development for the bovine is also significantly increased by IFNT treatment $(100 \mathrm{ng} / \mathrm{mL})$ in in vitro culture medium (Takahashi et al., 2003), suggesting that development of the embryo is regulated by IFNT in an autocrine manner during the preimplantation stage. In our study, supplemental IFNT treatment $(100 \mathrm{ng} / \mathrm{mL})$ not only increased the percentage of bovine embryos developing to the blas-

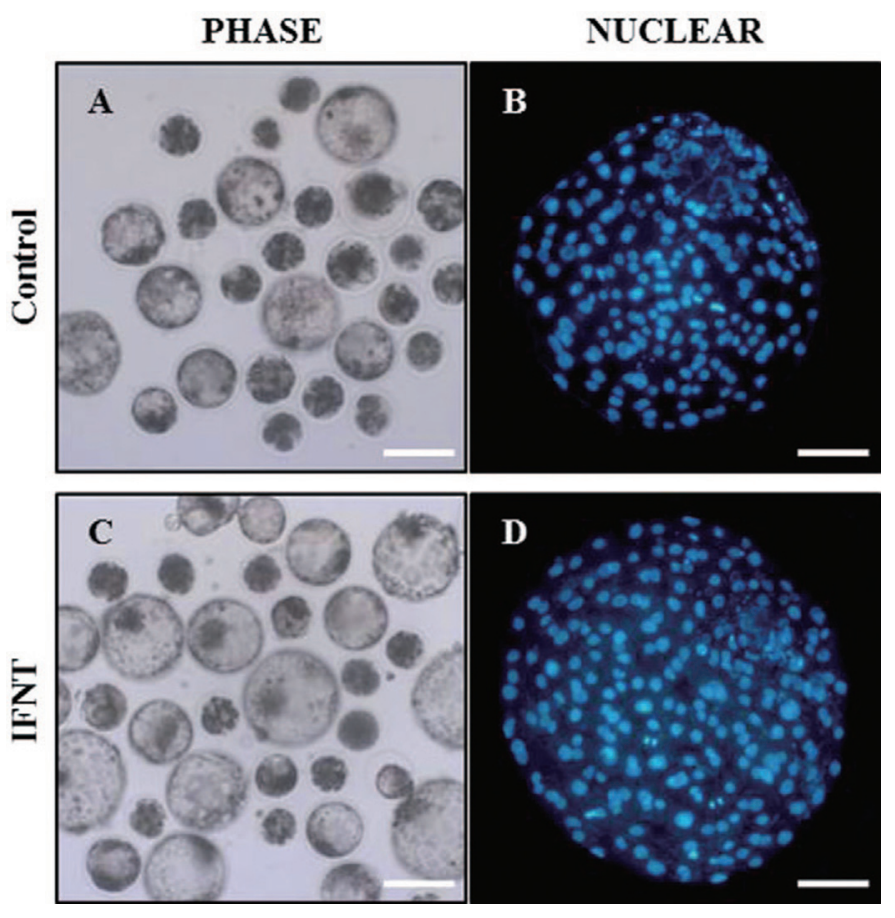

Figure 2. Interferon- $\tau$ (IFNT) promotes bovine embryo development to the blastocyst stage and increases cell number. Photomicrographs (phase contrast microscopy) of d 8 blastocysts in control (A) and IFNT-treated groups $(\mathrm{C})$; scale bar $=200 \mu \mathrm{m}$. Total cell numbers of $\mathrm{d}$ 8 blastocysts were counted after Hoechst 33342 staining; blastocysts of the same diameter $(350 \mu \mathrm{m})$ were selected for cell number counting in control (B) and IFNT-treated groups (D); scale bar $=100 \mu \mathrm{m}$. Color version available in the online PDF. 
A

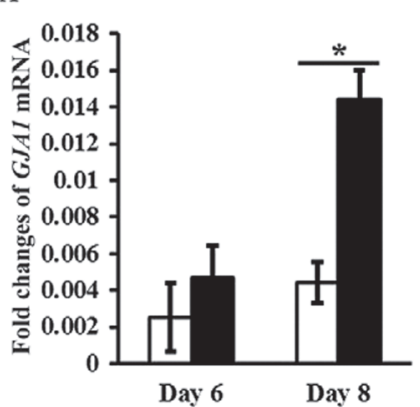

C

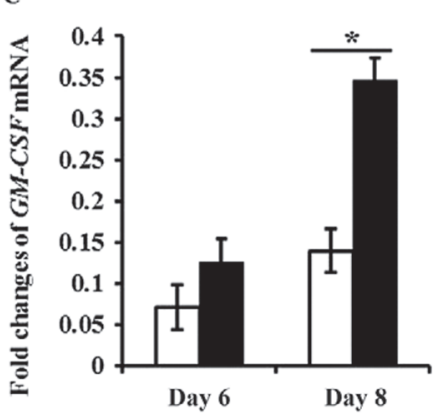

E

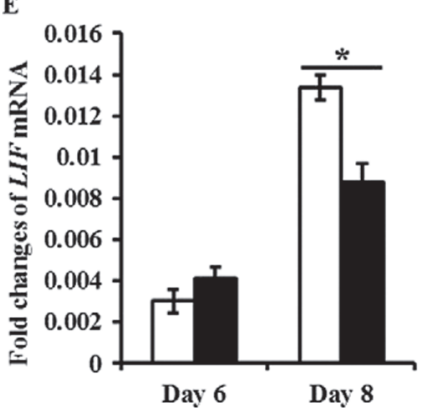

G

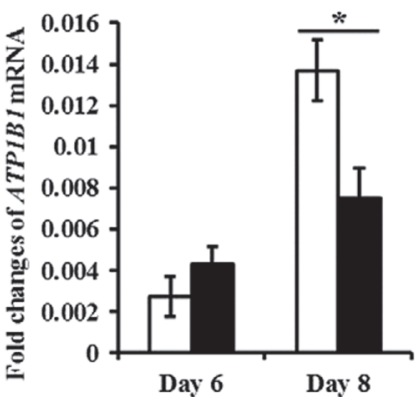

Figure 3. Interferon- $\tau$ (IFNT) affects expression of connexin 43 (GJA1), E-cadherin (CDH1), granulocyte-macrophage colony-stimulating factor (GM-CSF), insulin-like growth factor-II (IGF2), leukemia inhibitory factor (LIF), LIF receptor $\alpha$ (LIFR), and sodium/ potassium-transporting ATPase subunit $\beta-1$ (ATP1B1) in bovine embryos. Bovine embryos were treated with IFNT from d 4 after in vitro fertilization and collected at $\mathrm{d} 6$ and 8 . The graph demonstrates the quantitative reverse transcription-PCR results of (A) GJA1, (B) CDH1, (C) GM-CSF, (D) IGF2, (E) LIF, (F) LIFR, and (G) ATP1B1 mRNA expression levels. Values represent mean \pm SEM of 3 experiments; ${ }^{*} P<0.05$.
B
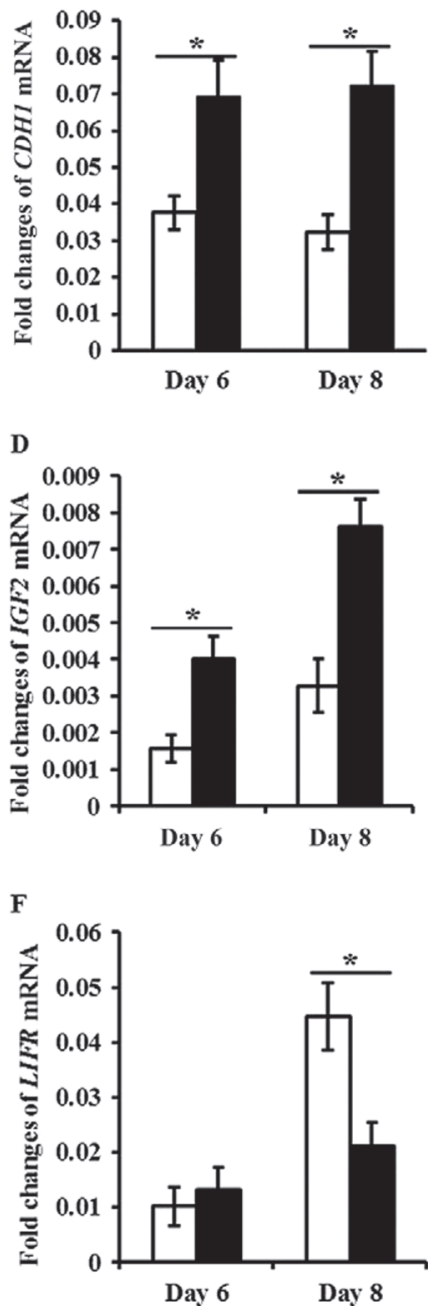

Control

IFNT

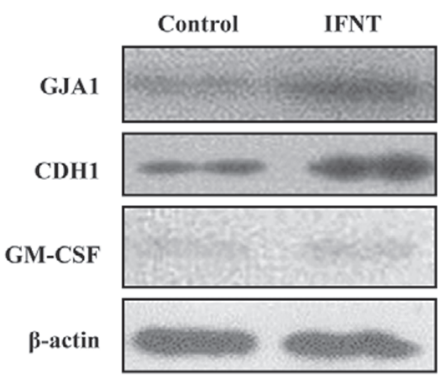

B

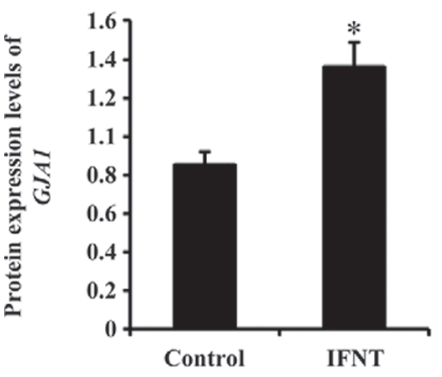

C
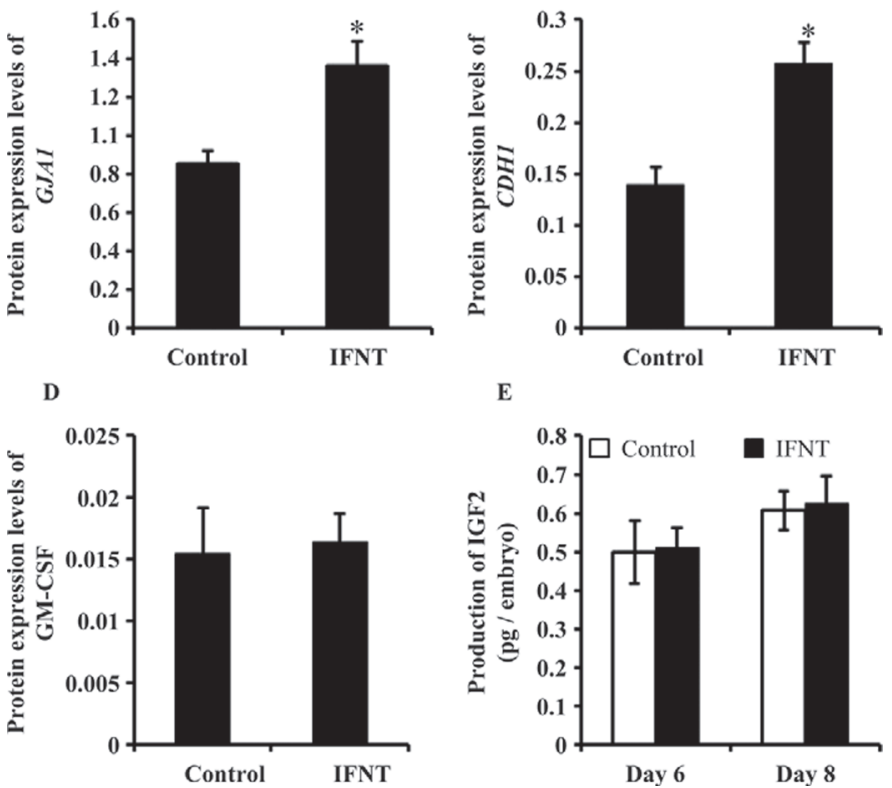

Figure 4. Effect of interferon- $\tau$ (IFNT) on the expression of connexin 43 (GJA1), E-cadherin (CDH1), granulocyte-macrophage colony-stimulating factor (GM-CSF), and insulin-like growth factor-II (IGF2) in d 8 embryos. (A) GJA1, CDH1, and GM-CSF protein expression detected with Western blot (a representative blot is shown). The graph demonstrates the results of the densitometric analysis of (B) GJA1, (C) CDH1, and (D) GM-CSF protein levels. The production of IGF2 in d 6 and 8 embryos was quantified with ELISA kits (E). Values represent mean \pm SEM of 3 experiments; ${ }^{*} P<0.05$.

tocyst stage, but also increased the total number of cells within the resulting blastocysts. In addition to its antiluteolytic actions, IFNT acts on the endometrium to induce or enhance the expression of several genes (IFNT-stimulated genes) that are hypothesized to regulate uterine receptivity to implantation and conceptus development (Hansen et al., 1999, Spencer et al., 2004).

Interferon- $\tau$ is a pivotal pregnancy signal in ruminants that is mediated through IFNAR ( $\mathrm{Li}$ and Roberts, 1994). The expression of IFNAR1 mRNA has been detected in d 5 morulas, d 7 early blastocysts, d 8 blastocysts, and expanded blastocysts of bovine embryos (Takahashi et al., 2003). Similarly, the present study found that both IFNAR1 and IFNAR2 mRNA 
were detected at the blastomere stage (d 4) and that the level of the IFNAR1 mRNA expression was increased from d 6 to 8 (Figure 1), indicating a possible role for IFNAR in regulating the mechanism underlying the autocrine function of IFN.

Niemann and Wrenzycki (2000) reported that the GJA1 gene is crucial for the maintenance of compaction in bovine embryos. After an injection of GJA1 double-stranded RNA at the zygote stage, the percentage of bovine embryos developing to the blastocyst stage was decreased by $18.4 \%$ in vitro (Tesfaye et al., 2007). Connexin 43 transcripts are detected in bovine morulas and blastocysts grown in vivo. By contrast, although the early developmental stages from COC to morulas expressed connexin 43 in vitro, no detectable GJA1 mRNA was found in the in vitro blastocysts and hatched blastocysts (Wrenzycki et al., 1996, 1998). However, in our study, GJA1 mRNA was detected at both the morula (d 6) and blastocyst (d 8) stages, and IFNT treatment significantly increased the expression of GJA1 mRNA in bovine blastocysts. This may be due, in part, to the addition of serum to our culture medium because the expression of GJA1 mRNA virtually disappeared from the 8- to 16-cell stage and on but reappeared in the hatched blastocysts in the serumreplete medium (Wrenzycki et al., 1999). Connexin 43 protein level was greater in the IFNT-treated group than that in the control group. As a type-I interferon, IFNT functions through the activation of the Jak-STAT signal transduction pathway (Darnell et al., 1994; Darnell, 1997) in bovine endometrial cells. Connexin 43 is reportedly activated by ciliary neurotrophic factor via the Jak-STAT pathway in murine cortical astrocytes (Ozog et al., 2004), indicating that the IFNT-promoted expression of GJA1 may also be via the Jak-STAT pathway in the bovine blastocyst.

Blastocyst formation is driven by the expression of specific sets of gene products that direct the acquisition of cell polarity within the trophectoderm. Critical genes controlling this event include mainly $C D H 1$ and sodium-potassium ATPase (Watson and Barcroft, 2001). Mice embryos carrying a homozygous mutation in the $C D H 1$ gene were initially able to compact but did not sustain the compacted state (Riethmacher et al., 1995). Moreover, injection of $C D H 1$ double-stranded RNA decreases either the relative expression of $C D H 1$ in bovine morulas and blastocysts or the percentages of embryos developing to the blastocyst stage (Tesfaye et al., 2007). We also demonstrated that the levels of the CDH1 mRNA and protein expression in the bovine blastocyst were greater in the IFNT-treated group than in the control group in d 8 embryos, indicating that CDH1 may be the key factor mediating the promoting effect of IFNT. The sodium-potassium ATPase drives the movement of water through aquaporins across the epithelium into the extracellular space of the blastocyst to form the fluid-filled blastocoel during blastocyst formation (Watson and Barcroft, 2001). Transcripts encoding the ATP1B1 isoform were detected within zygotes, morulas, and blastocyst stages, but not in 2-, $4-$, or 8-cell embryos, raising the possibility that the $\beta$ subunit performs an essential role in coordinating the onset and progression of cavitation in the mouse embryo (Watson et al., 1990). In our study, the addition of IFNT did not affect the expression of ATP1B1 in $d$ 6 embryos, and significantly decreased its expression in $\mathrm{d} 8$ embryos compared with the appropriate control groups.

Supplementing with IGF2, GM-CSF, and LIF significantly accelerates bovine embryonic development, especially in the change from the expanded blastocyst to hatched blastocyst stage (Neira et al., 2010). The addition of IGF2 to the culture medium appears beneficial because it increases the number of embryos that develop to the blastocyst stage in bovine embryo production (Block et al., 2008). The expression of GMCSF is stimulated by IFNT in both bovine leukocytes and endometrial stromal cells (Emond et al., 2004). The cytokine LIF facilitates the development of the morula to the blastocyst, improves hatching rate, and increases the cell number in the inner cell mass (Martal et al., 1998). Consistent with those observations, we demonstrated that the supplementation of IFNT in the culture medium resulted in a significant increase in the expression of GM-CSF mRNA in d 8 embryos. However, IFNT had no effect on the expression of the GM-CSF protein at the same stage, suggesting that GM-CSF might not be directly involved in the promoting effect of IFNT. We also found that the hatched blastocyst rate was not affected by the addition of IFNT, which might be because IFNT induced an increase in the expression levels for IGF2 and GM-CSF mRNA but not their proteins, and because IFNT inhibited the expression of LIF, LIFR, and ATP1B1 mRNA in d 8 embryos. Further study on the mechanisms of the IFNT regulation of important candidate genes is required to fully elucidate embryonic development and differentiation in mammals.

\section{ACKNOWLEDGMENTS}

The authors thank R. Michael Roberts (University of Missouri, Columbia) for providing the recombinant bovine IFNT. This work was supported by a grant from the National Natural Science Foundation of China (Beijing, China; grant no. 31172209). 


\section{REFERENCES}

Assal-Meliani, A., R. Kinsky, J. Martal, and G. Chaouat. 1995. In vivo immunosuppressive effects of recombinant ovine interferontau (trophoblastin): r.oTP (r.oIFN-tau) inhibits local GVH reaction in mice (PLN assay), prevents fetal resorptions, and favors embryo survival and implantation in the $\mathrm{CBA} / \mathrm{J} \times \mathrm{DBA} / 2$ mice combination. Am. J. Reprod. Immunol. 33:267-275.

Bartol, F. F., R. M. Roberts, F. W. Bazer, G. S. Lewis, J. D. Godkin, and W. W. Thatcher. 1985. Characterization of proteins produced in vitro by periattachment bovine conceptuses. Biol. Reprod. 32:681-693.

Betts, D. H., D. J. MacPhee, G. M. Kidder, and A. J. Watson. 1997. Ouabain sensitivity and expression of $\mathrm{Na} / \mathrm{K}$-ATPase $\alpha$ - and $\beta$-subunit isoform genes during bovine early development. Mol. Reprod. Dev. 46:114-126.

Block, J., C. Wrenzycki, H. Niemann, D. Herrmann, and P. J. Hansen 2008. Effects of insulin-like growth factor-1 on cellular and molecular characteristics of bovine blastocysts produced in vitro. Mol. Reprod. Dev. 75:895-903.

Brackett, B. G., and G. Oliphant. 1975. Capacitation of rabbit spermatozoa in vitro. Biol. Reprod. 12:260-274.

Carthew, P., M. Wood, and C. Kirby. 1986. Mouse interferon produced in vivo does not inhibit the development of preimplantation mouse embryos. J. Reprod. Fertil. 77:75-79.

Darnell, J. E. 1997. STATs and gene regulation. Science 277:16301635.

Darnell, J. E., I. Kerr, and G. Stark. 1994. Jak-STAT pathways and transcriptional activation in response to IFNs and other extracellular signaling proteins. Science 264:1415-1421.

de Moraes, A. A., and P. J. Hansen. 1997. Granulocyte-macrophage colony-stimulating factor promotes development of in vitro produced bovine embryos. Biol. Reprod. 57:1060-1065.

De Sousa, P. A., S. C. Juneja, S. Caveney, F. D. Houghton, T. C. Davies, A. G. Reaume, J. Rossant, and G. M. Kidder. 1997. Normal development of preimplantation mouse embryos deficient in gap junctional coupling. J. Cell Sci. 110:1751-1758.

Emond, V., L. A. MacLaren, S. Kimmins, J. A. Arosh, M. A. Fortier, and R. D. Lambert. 2004. Expression of cyclooxygenase-2 and granulocyte-macrophage colony-stimulating factor in the endometrial epithelium of the cow is up-regulated during early pregnancy and in response to intrauterine infusions of interferon-tau. Biol. Reprod. 70:54-64.

Geisert, R. D., M. T. Zavy, B. G. Biggers, J. E. Garrett, and R. P. Wettemann. 1988. Characterization of the uterine environment during early conceptus expansion in the bovine. Anim. Reprod. Sci. 16:11-25.

Han, C. S., N. Mathialagan, S. W. Klemann, and R. M. Roberts. 1997. Molecular cloning of ovine and bovine type I interferon receptor subunits from uteri, and endometrial expression of messenger ribonucleic acid for ovine receptors during the estrous cycle and pregnancy. Endocrinology 138:4757-4767.

Hansen, T. R., K. J. Austin, D. J. Perry, J. K. Pru, M. G. Teixeira, and G. A. Johnson. 1999. Mechanism of action of interferon-tau in the uterus during early pregnancy. J. Reprod. Fertil. Suppl. 54:329-339.

Harvey, M. B., and P. L. Kaye. 1992. IGF-2 stimulates growth and metabolism of early mouse embryos. Mech. Dev. 38:169-173.

Imakawa, K., K. Tamura, R. S. Lee, Y. Ji, H. Kogo, S. Sakai, and R. K. Christenson. 2002. Temporal expression of type I interferon receptor in the peri-implantation ovine extra-embryonic membranes: demonstration that human IFNalpha can bind to this receptor. Endocr. J. 49:195-205.

Li, J., and R. M. Roberts. 1994. Interferon-tau and interferon-alpha interact with the same receptors in bovine endometrium. Use of a readily iodinatable form of recombinant interferon-tau for binding studies. J. Biol. Chem. 269:13544-13550.

Livak, K. J., and T. D. Schmittgen. 2001. Analysis of relative gene expression data using real-time quantitative PCR and the $2^{-\triangle \Delta \mathrm{CT}}$ method. Methods 25:402-408.
Madan, P., K. Rose, and A. J. Watson. 2007. Na/K-ATPase $\beta 1$ subunit expression is required for blastocyst formation and normal assembly of trophectoderm tight junction-associated proteins. J. Biol. Chem. 282:12127-12134.

Martal, J. L., N. M. Chene, L. P. Huynh, R. M. L'Haridon, P. B. Reinaud, M. W. Guillomot, M. A. Charlier, and S. Y. Charpigny. 1998. IFN-tau: A novel subtype I IFN1. Structural characteristics, non-ubiquitous expression, structure-function relationships, a pregnancy hormonal embryonic signal and cross-species therapeutic potentialities. Biochimie 80:755-777.

Neira, J. A., D. Tainturier, M. A. Pena, and J. Martal. 2010. Effect of the association of IGF-I, IGF-II, bFGF, TGF-beta1, GM-CSF, and LIF on the development of bovine embryos produced in vitro. Theriogenology 73:595-604.

Niemann, H., and C. Wrenzycki. 2000. Alterations of expression of developmentally important genes in preimplantation bovine embryos by in vitro culture conditions: Implications for subsequent development. Theriogenology 53:21-34.

Ozog, M. A., S. M. Bernier, D. C. Bates, B. Chatterjee, C. W. Lo, and C. C. G. Naus. 2004. The complex of ciliary neurotrophic factorciliary neurotrophic factor receptor $\alpha$ up-regulates connexin 43 and intercellular coupling in astrocytes via the Janus tyrosine kinase/ signal transducer and activator of transcription pathway. Mol. Biol. Cell 15:4761-4774.

Payelle-Brogard, B., and S. Pellegrini. 2010. Biochemical monitoring of the early endocytic traffic of the type I interferon receptor. J. Interferon Cytokine Res. 30:89-98.

Rappolee, D. A., K. S. Sturm, O. Behrendtsen, G. A. Schultz, R. A. Pedersen, and Z. Werb. 1992. Insulin-like growth factor II acts through an endogenous growth pathway regulated by imprinting in early mouse embryos. Genes Dev. 6:939-952.

Riethmacher, D., V. Brinkmann, and C. Birchmeier. 1995. A targeted mutation in the mouse E-cadherin gene results in defective preimplantation development. Proc. Natl. Acad. Sci. USA 92:855-859.

Rizos, D., A. Gutiérrez-Adán, S. Pérez-Garnelo, J. de la Fuente, M. P. Boland, and P. Lonergan. 2003. Bovine embryo culture in the presence or absence of serum: Implications for blastocyst development, cryotolerance, and messenger RNA expression. Biol. Reprod. 68:236-243.

Rizos, D., P. Lonergan, M. P. Boland, R. Arroyo-Garcia, B. Pintado, J. de la Fuente, and A. Gutierrez-Adan. 2002. Analysis of differential messenger RNA expression between bovine blastocysts produced in different culture systems: Implications for blastocyst quality. Biol. Reprod. 66:589-595.

Ruef, C., and D. L. Coleman. 1990. Granulocyte-macrophage colonystimulating factor: Pleiotropic cytokine with potential clinical usefulness. Rev. Infect. Dis. 12:41-62.

Spencer, T. E., G. A. Johnson, F. W. Bazer, and R. C. Burghardt. 2004. Implantation mechanisms: Insights from the sheep. Reproduction 128:657-668.

Takahashi, M., H. Takahashi, S. Hamano, S. Watanabe, S. Inumaru, M. Geshi, K. Okuda, Y. Yokomizo, and A. Okano. 2003. Possible role of interferon-tau on in vitro development of bovine embryos. J. Reprod. Dev. 49:297-305.

Tesfaye, D., P. Lonergan, M. Hoelker, F. Rings, K. Nganvongpanit, V. Havlicek, U. Besenfelder, D. Jennen, E. Tholen, and K. Schellander. 2007. Suppression of connexin 43 and E-cadherin transcripts in in vitro derived bovine embryos following culture in vitro or in vivo in the homologous bovine oviduct. Mol. Reprod. Dev. 74:978-988.

Wang, X. L., K. Wang, G. C. Han, and S. M. Zeng. 2013. A potential autocrine role for interferon tau in ovine trophectoderm. Reprod. Domest. Anim. 48:819-825.

Watson, A. J., and L. C. Barcroft. 2001. Regulation of blastocyst formation. Front. Biosci. 6:D708-D730.

Watson, A. J., C. Pape, J. R. Emanuel, R. Levenson, and G. M. Kidder. 1990. Expression of Na,K-ATPase alpha and beta subunit genes during preimplantation development of the mouse. Dev. Genet. 11:41-48.

Wrenzycki, C., D. Hermann, E. Lemme, K. Korsawe, J. W. Carnwath, and H. Niemann. 1998. Transcriptional level of developmentally 
important genes in bovine preimplantation embryos generated in vitro. Theriogenology 49:191.

Wrenzycki, C., D. Herrmann, J. W. Carnwath, and H. Niemann. 1996. Expression of the gap junction gene connexin43 (Cx43) in preimplantation bovine embryos derived in vitro or in vivo. J. Reprod. Fertil. 108:17-24.

Wrenzycki, C., D. Herrmann, J. W. Carnwath, and H. Niemann. 1999. Alterations in the relative abundance of gene transcripts in preim- plantation bovine embryos cultured in medium supplemented with either serum or PVA. Mol. Reprod. Dev. 53:8-18.

Wrenzycki, C., D. Wells, D. Herrmann, A. Miller, J. Oliver, R. Tervit, and H. Niemann. 2001. Nuclear transfer protocol affects messenger RNA expression patterns in cloned bovine blastocysts. Biol. Reprod. 65:309-317. 